\title{
Microbiological evaluation of lettuce produced by conventional and organic systems in farms of Londrina, PR
}

\author{
Avaliação microbiológica de alfaces produzidas pelos sistemas \\ convencional e orgânico em propriedades rurais de Londrina,PR
}

\author{
Natalia Harumi Niguma ${ }^{1 *}$; Jacinta Sanchez Pelayo ${ }^{2}$; \\ Tereza Cristina Rocha Moreira de Oliveira $^{3}$
}

\begin{abstract}
The aims of this study were to evaluate the contamination of lettuce (Lactuca sativa), produced in Londrina, Paraná (PR), with total coliform, coliform at $45{ }^{\circ} \mathrm{C}$, E. coli, and Salmonella spp.; and to determine the E. coli contamination of irrigation water used at the farms studied. Four farms were evaluated, of which three produced lettuce using a conventional system and one using an organic system. An evaluation of the production practices of the farms was also carried out. A total of 111 samples were analyzed, 71 lettuce samples from the conventional system and 40 samples from the organic system. A total of eight irrigation water samples were collected for analysis. Coliform at $45^{\circ} \mathrm{C}$ counts above the limit tolerated by Brazilian legislation were observed in $2.8 \%(2 / 71)$ of conventionally grown lettuce samples, and Salmonella spp. was isolated in 1.4\% (1/71) of those samples. In the organic lettuce samples, $12.5 \%(5 / 40)$ had coliform at $45{ }^{\circ} \mathrm{C}$ counts above the limit tolerated and Salmonella spp. was not detected. Irrigation water samples from three farms were unsatisfactory, with counts higher than $10^{2} \mathrm{MPN}$ of E. coli per $100 \mathrm{~mL}$. The results of this study demonstrate that most conventionally grown lettuce samples show good sanitary conditions in production, and that lettuce contamination is not related to contamination found in irrigation water samples. The results also showed that the organic production practices required by Brazilian certification agencies should be applied to ensure that contamination of produced lettuce remains controlled.
\end{abstract}

Key words: Coliform at $45^{\circ} \mathrm{C}$. Total coliform.Salmonella spp. Irrigation water.

\section{Resumo}

Os objetivos deste estudo foram avaliar a contaminação por coliformes totais, coliformes a $45{ }^{\circ} \mathrm{C}$, Escherichia coli e Salmonella spp. em alfaces crespas (Lactuca sativa) produzidas na região de Londrina, PR, e a contaminação por E. coli das amostras da água de irrigação empregadas nas propriedades estudadas. Quatro propriedades rurais foram avaliadas, das quais três produziam alfaces pelo sistema convencional e uma pelo sistema orgânico. Avaliação das práticas de produção dessas propriedades também foi realizada. Um total de 111 amostras foi coletado, sendo 71 amostras de produção convencional e 40 amostras de produção orgânica. Oito amostras de água de irrigação foram coletadas para análise. Contagens de coliformes a $45{ }^{\circ} \mathrm{C}$ acima do tolerado pela legislação brasileira foram observadas em 2,8\% (2/71) das alfaces convencionais analisadas, e Salmonella spp. foi isolada em 1,4 \% (1/71) destas amostras. Quanto às amostras orgânicas, 12,5 \% (5/40) apresentaram contagens

\footnotetext{
${ }^{1}$ Discente Curso de Doutorado, Programa de Pós-Graduação em Ciência de Alimentos, Departamento de Ciência e Tecnologia de Alimentos, Universidade Estadual de Londrina, UEL, Londrina, PR, Brasil. E-mail: natalianiguma@gmail.com

2 Prof ${ }^{\mathrm{a}} \mathrm{Dr}^{\mathrm{a}}$, Laboratório de Bacteriologia, Departamento de Microbiologia do Centro de Ciências Biológicas, UEL, Londrina, PR. E-mail: jspelayo@sercomtel.com.br

${ }^{3}$ Prof $^{\mathrm{a}} \mathrm{Dr}^{\mathrm{a}}$, Departamento de Ciência e Tecnologia de Alimentos, UEL, PR. E-mail: terezaoliveira@yahoo.com

* Author for correspondence
} 
de coliformes a $45{ }^{\circ} \mathrm{C}$ acima do limite preconizado e Salmonella spp. não foi isolada nessas amostras. As amostras de água de irrigação de três propriedades rurais apresentaram resultados insatisfatórios com contagens superiores a $10^{2} \mathrm{MPN}$ de $E$. coli por $100 \mathrm{~mL}$. Os resultados obtidos neste estudo mostraram que a maioria das amostras de alfaces convencionais analisadas apresentou boas condições higiênicosanitárias e uma não relação com a contaminação encontrada nas amostras de água de irrigação. Os resultados também mostraram que as práticas de produção orgânica exigidas pelas certificadoras devem ser aplicadas para que a contaminação destes alimentos permaneça sob controle.

Palavras-chave: Coliformes a $45^{\circ} \mathrm{C}$. Coliformes totais. Salmonella spp. Água de irrigação.

\section{Introduction}

The consumption of raw vegetables can be an important cause of food-borne diseases, and contamination can occur any at time between cultivation and handling by the consumer (ABREU et al., 2010). Raw vegetables, such as lettuce and spinach, have been identified as sources of diarrheagenic Escherichia coli in several outbreaks in the United States (CDC, 2014a). Salmonellosis outbreaks have also been attributed to the consumption of vegetables such as cucumber, melon, mango and alfalfa sprouts (CDC, 2014b).

Salmonella spp. accounted for $18.09 \%$, and E. coli for $6.33 \%$, of the foodborne outbreaks that occurred in Brazil between 2000 and 2014. Contamination of vegetables accounted for $1.25 \%$ of those outbreaks (SVS, 2014). The number of cases and outbreaks involving these bacteria is likely to be much higher, since they are often not reported to the Brazilian Sanitary Surveillance Agency.

Manure is the main fertilizer used in organic production and its microbiological safety is often a significant concern raised about the production of fruits and vegetables using organic methods. The use of water containing human pathogens may contaminate the edible portions of lettuce. In addition, irrigation methods vary, and may have varying potential to introduce or promote human pathogen growth on lettuce (DOYLE; ERICKSON, 2008).

The objectives of this study were to evaluate the total coliform, coliform at $45{ }^{\circ} \mathrm{C}, E$. coli and Salmonella spp. in lettuce (Lactuca sativa) produced by conventional and organic systems in four rural properties in Londrina, Paraná (PR), Brazil, and to evaluate the $E$. coli contamination of irrigation water from those properties.

\section{Material and Methods}

\section{Sampling}

The microbiological analyses were performed at the Food Microbiology Laboratory, Agricultural Sciences Center, State University of Londrina (UEL), Londrina, PR. Each sample consisted of a head of green leaf lettuce. Lettuce heads were collected, wrapped in polyethylene bags, transported to the laboratory in thermal boxes, and analyzed on the same day. Lettuce heads were randomly collected from four farms. Three farms employed a conventional production system and were designated A, B and C; one farm employed an organic production system and was designated D. A total of 111 lettuce head samples were analyzed (71 from conventional production farms and 40 from the organic system farm). Samples from the same lot were collected before and after the washing process. The total number of samples collected from each farm, the number of batches analyzed and the number of samples analyzed in each batch are shown in Table 1.

\section{Lettuce washing procedures}

Lettuce washing procedures were different at each farm. The authors of this study chose not to interfere with the procedure performed a teach farm, in order to assess the possible differences in contamination among the samples collected. 
Table 1. Number of samples analyzed from each farm, and number of lettuce heads analyzed per lot before and after washing.

\begin{tabular}{|c|c|c|c|}
\hline Farm & $\begin{array}{c}\text { Number of samples } \\
\mathrm{n}=111\end{array}$ & $\begin{array}{c}\text { Before washing* } \\
\text { Number of lettuce head }\end{array}$ & $\begin{array}{c}\text { After washing** } \\
\text { Number of lettuce head }\end{array}$ \\
\hline $\mathbf{A}$ & 30 & $\begin{array}{l}1^{\text {st }} l o t-5 \\
2^{\text {nd }} l o t-5 \\
3^{\text {rd }} l o t-5\end{array}$ & $\begin{array}{l}1^{\text {st }} \text { lot }-5 \\
2^{\text {nd }} \text { lot }-5 \\
3^{\text {rd }} \text { lot }-5\end{array}$ \\
\hline B & 19 & $1^{\text {st }} \operatorname{lot}-9$ & $1^{\text {st }} \operatorname{lot}-10$ \\
\hline C & 22 & $\begin{array}{c}1^{\text {stlot- } 5} \\
2^{\text {nd }} \operatorname{lot}-6\end{array}$ & $\begin{array}{l}1^{\text {st }} \text { lot }-5 \\
2^{\text {nd }} \text { lot }-6\end{array}$ \\
\hline D & 40 & $\begin{array}{c}1^{\text {st }} \operatorname{lot}-5 \\
2^{\text {nd }} \operatorname{lot}-5 \\
3^{\text {rd }} \text { lot }-10\end{array}$ & $\begin{array}{c}1^{\text {st }} \text { lot }-5 \\
2^{\text {nd }} \operatorname{lot}-5 \\
3^{\text {rd }} \text { lot }-10 \\
\end{array}$ \\
\hline
\end{tabular}

* Lots and number of lettuce heads analyzed per lot before the washing procedure.

** Lots and number of lettuce heads analyzed per lot after the washing procedure.

The lettuce washing procedure at farm A was performed with running water from an artesian well, without sodium hypochlorite. Farm B had dirty area for vegetable washing, where lettuce heads were dipped into a large reservoir containing artesian well water without sodium hypochlorite. At farm $\mathrm{C}$, lettuce heads were dipped into a small tank containing water from an artesian well, and no sanitizer was used. At farm D, the lettuce washing procedure included a rinse with artesian water, followed by a sanitization step with sodium hypochlorite water (at $200 \mathrm{ppm}$ ), and finally a rinse in clean water to remove residual hypochlorite.

Total coliform, coliform at $45^{\circ} \mathrm{C}$, and E. coli counts

A 25-g sample of edible leaves from each lettuce head was placed in a sterile plastic bag and homogenized with $225 \mathrm{~mL}$ of buffered peptone water broth (BPW), and a 10-fold dilution was prepared. The most probable number method (MPN/g) was used for total and coliform at $45{ }^{\circ} \mathrm{C}$ counts. E. coli counts were performed as described by Silva et al. (2007a).

\section{Salmonella spp. detection}

Salmonella spp. detection was performed using the conventional culture method described by Silva et al. (2007b) and polymerase chain reaction (PCR). For the PCR assay, 25-g samples were homogenized with $225 \mathrm{~mL}$ of BPW and incubated at $37{ }^{\circ} \mathrm{C}$ for 24 h. Aliquots of $1.0 \mathrm{~mL}$ of this enrichment were used for DNA extraction. PCR conditions and amplicon visualization were as described by Alves et al. (2012).

\section{Microbiological evaluation of irrigation water}

A total of eight samples of irrigation water were collected from the different farms. Each sample was collected on the same day as the lettuce samples. Irrigation water samples were collected in glass flasks and transported at $4{ }^{\circ} \mathrm{C}$ to the Bacteriological Laboratory, Department of Microbiology, Biology Science Center, UEL, Londrina, PR. The Colilert ${ }^{\circledR}$ technique (SOVEREIGN - USA), approved by the Brazilian Health Ministry (BRASIL, 2012) and described by Chao (2006), was used for total coliform and E. coli detection and quantification. 


\section{Results and Discussion}

Evaluation of hygienic and sanitary conditions of lettuce produced using a conventional system

The counts of total coliform, coliform at $45{ }^{\circ} \mathrm{C}$ and $E$. coli of lettuce samples obtained before and after the washing procedure performed at farms A, B and $\mathrm{C}$ are shown in Table 2.Farms $\mathrm{A}$ and $\mathrm{B}$ had high monthly production and daily harvest. These farms had more employees and produced vegetables other than lettuce that were harvested simultaneously. The microbiological results obtained indicated that the washing procedure carried out at farm A was adequate. However, counts of total coliform and coliform at $45{ }^{\circ} \mathrm{C}$ obtained from samples collected at farm B were not uniform. Some samples had the same count before and after washing and others had higher counts after the washing procedure.

Harvests were gathered weekly at farm C, with few employees, and conducted carefully and slowly. In these conditions, contamination of lettuce with soil was low, which may explain the lower coliform counts in most samples, even before washing.

Although the total coliform count in most samples collected from farm $B$, both before and after washing, was above $2.4 \times 10^{3} \mathrm{MPN} \mathrm{g}^{-1}$, none of the samples had counts above $10^{2} \mathrm{MPN} / \mathrm{g}$, which is the limit established by RDC n ${ }^{\circ} 12 / 2001$ (BRASIL, 2001) for vegetables in natura. The absence of coliform at $45^{\circ} \mathrm{C}$ in these samples can be explained by the high use of pesticides and fertilizer sat farm B. According to Guan et al. (2005), some pesticides applied in gardens may have inhibitory effects on pathogenic bacteria.
Coliform at $45^{\circ} \mathrm{C}$ counts were above the limit set by Brazilian legislation in 2.8\% (2/71) of the samples produced by the conventional system. One of these samples was collected at farm C $\left(1.5 \times 10^{2} \mathrm{MPN}^{-1}\right)$ before the washing procedure. The other was collected at farm A $\left(1.1 \times 10^{3} \mathrm{MPN} g\right.$ ${ }^{-1}$ ) after the washing procedure.

Vegetables produced using the conventional system and sold in street markets inLondrina, PR, were not contaminated with $E$. coli, although $26.9 \%$ $(7 / 26)$ of the samples had coliform at $45{ }^{\circ} \mathrm{C}$ counts above the limit set by Brazilian legislation (SILVA et al., 2006). Johannessen et al. (2002) analyzed 200 samples of lettuce purchased in grocery stores in Norway, and found that only $2.5 \%$ of the samples $(5 / 200)$ were contaminated with E. coli. Other studies conducted in Brazil have reported high levels of contamination of produce with coliform at $45{ }^{\circ} \mathrm{C}$. Takayanagui et al. (2001) reported that $67 \%$ $(77 / 115)$ of the grocery stores and street markets examined in Ribeirão Preto, São Paulo, were found to have produce contaminated with coliform at 45 ${ }^{\circ} \mathrm{C}$ above the limit required by Brazilian legislation. Gomes Neto et al. (2012) also observed high counts of coliform at $45{ }^{\circ} \mathrm{C}$ in $66 \%(20 / 30)$ of lettuce samples produced by a conventional system.

In this study, a lettuce sample produced by the conventional system at farm A (1/71) was contaminated with Salmonella spp. It was isolated using the traditional culture method and its presence was confirmed by PCR. This sample was analyzed before the washing procedure; therefore, it could be assumed that proper sanitization may eliminate this contamination. 
Table 2. Counts of total coliform, coliform at $45^{\circ} \mathrm{C}$ and E. coli obtained from lettuce samples produced at three farms by a conventional cropping system, before and after washing.

\begin{tabular}{|c|c|c|c|c|c|c|c|}
\hline \multirow{3}{*}{ Farms } & \multirow{3}{*}{ Lots* } & \multicolumn{6}{|c|}{ Counts MPN .g ${ }^{-1}$} \\
\hline & & \multicolumn{3}{|c|}{ Before washing } & \multicolumn{3}{|c|}{ After washing } \\
\hline & & Total Coliform & Coliform at $45^{\circ} \mathrm{C}$ & E. coli & Total Coliform & Coliform at $45^{\circ} \mathrm{C}$ & E. coli \\
\hline \multirow{16}{*}{$\mathbf{A}$} & \multirow{5}{*}{1} & $\geq 2400$ & $<3$ & NI & 240 & $<3$ & $\mathrm{NI}$ \\
\hline & & 460 & $<3$ & NI & 93 & 9 & 9 \\
\hline & & 240 & $<3$ & NI & 43 & 4 & 4 \\
\hline & & 43 & $<3$ & NI & 43 & $<3$ & NI \\
\hline & & 43 & $<3$ & NI & 23 & $<3$ & NI \\
\hline & \multirow{5}{*}{2} & $\geq 2400$ & 93 & 4 & $\geq 2400$ & 1100 & 1100 \\
\hline & & 460 & 93 & 23 & 43 & 3 & NI \\
\hline & & 460 & 15 & 9 & 43 & $<3$ & NI \\
\hline & & 93 & 23 & 23 & 43 & $<3$ & NI \\
\hline & & 39 & 4 & 4 & 9 & 4 & 4 \\
\hline & \multirow{15}{*}{1} & $* * \geq 2400$ & 43 & 15 & $\geq 2400$ & 21 & 14 \\
\hline & & $\geq 2400$ & 7 & 3 & $\geq 2400$ & $<3$ & NI \\
\hline & & $\geq 2400$ & 23 & 14 & $\geq 2400$ & 4 & NI \\
\hline & & $\geq 2400$ & 14 & 14 & $\geq 2400$ & 7 & 3 \\
\hline & & 21 & $<3$ & $<3$ & 120 & 14 & 11 \\
\hline & & 1100 & $<3$ & NI & $\geq 2400$ & $<3$ & NI \\
\hline \multirow{9}{*}{ B } & & 460 & $<3$ & NI & 240 & $<3$ & NI \\
\hline & & 460 & $<3$ & NI & 240 & $<3$ & NI \\
\hline & & 150 & $<3$ & NI & 23 & $<3$ & NI \\
\hline & & 15 & $<3$ & NI & 4 & $<3$ & NI \\
\hline & & $\geq 2400$ & 11 & NI & $\geq 2400$ & 4 & NI \\
\hline & & $\geq 2400$ & 4 & NI & $\geq 2400$ & $<3$ & NI \\
\hline & & $\geq 2400$ & 4 & NI & $\geq 2400$ & $<3$ & NI \\
\hline & & $\geq 2400$ & $<3$ & NI & $\geq 2400$ & $<3$ & NI \\
\hline & & & & & 1100 & $<3$ & NI \\
\hline \multirow{11}{*}{ C } & \multirow{5}{*}{1} & 150 & 150 & 150 & 23 & $<3$ & NI \\
\hline & & 23 & 9 & 9 & 23 & $<3$ & NI \\
\hline & & 23 & 4 & 4 & 9 & $<3$ & NI \\
\hline & & 23 & 4 & NI & 7 & $<3$ & NI \\
\hline & & 4 & 4 & 4 & $<3$ & $<3$ & NI \\
\hline & \multirow{6}{*}{2} & $\geq 2400$ & $<3$ & NI & 23 & $<3$ & NI \\
\hline & & 9 & $<3$ & NI & 23 & $<3$ & NI \\
\hline & & 4 & $<3$ & NI & 4 & $<3$ & NI \\
\hline & & 4 & $<3$ & NI & 3 & $<3$ & NI \\
\hline & & 3 & $<3$ & NI & 3 & $<3$ & NI \\
\hline & & 3 & $<3$ & NI & 3 & $<3$ & NI \\
\hline
\end{tabular}

NI: Not isolated

* The lots were composed of heads of lettuce taken on different days.

** Presence of Salmonella spp. 
Evaluation of hygienic and sanitary conditions of lettuce produced using an organic system

Counts of total coliform, coliform at $45{ }^{\circ} \mathrm{C}$ and E. coli of lettuce samples harvested at farm D are shown in Table 3. Coliform at $45{ }^{\circ} \mathrm{C}$ counts were above the limit set by Brazilian legislation in $12.5 \%$ $(5 / 40)$ of samples, two of which were collected before, and three after, the washing procedure. All were collected from lot 3 .

Table 3. Counts of total coliform, coliform at $45^{\circ} \mathrm{C}$ and E. coli obtained from lettuce samples produced byone farm using an organic cropping system, before and after washing.

\begin{tabular}{|c|c|c|c|c|c|c|c|}
\hline \multirow{3}{*}{ Farm } & \multirow{3}{*}{ Lots* } & \multicolumn{6}{|c|}{ Counts MPN . $\mathrm{g}^{-1}$} \\
\hline & & \multicolumn{3}{|c|}{ Before washing } & \multicolumn{3}{|c|}{ After washing } \\
\hline & & Total Coliform & Coliform at $45^{\circ} \mathrm{C}$ & E. coli & Total Coliform & Coliform at $45^{\circ} \mathrm{C}$ & E. coli \\
\hline \multirow{20}{*}{ D } & \multirow{5}{*}{1} & 1100 & $<3$ & NI & $<3$ & $<3$ & NI \\
\hline & & 460 & $<3$ & NI & $<3$ & $<3$ & NI \\
\hline & & 93 & 4 & NI & $<3$ & $<3$ & NI \\
\hline & & 28 & 9 & NI & $<3$ & $<3$ & NI \\
\hline & & 9 & $<3$ & NI & $<3$ & $<3$ & NI \\
\hline & \multirow{5}{*}{2} & 460 & $<3$ & NI & 43 & $<3$ & NI \\
\hline & & 93 & $<3$ & NI & 15 & $<3$ & NI \\
\hline & & 39 & $<3$ & NI & $<3$ & $<3$ & NI \\
\hline & & 4 & $<3$ & NI & $<3$ & $<3$ & NI \\
\hline & & $<3$ & $<3$ & NI & $<3$ & $<3$ & NI \\
\hline & \multirow{10}{*}{3} & $\geq 2400$ & 1100 & 1100 & $\geq 2400$ & $\geq 2400$ & 28 \\
\hline & & $\geq 2400$ & 210 & 3 & $\geq 2400$ & 460 & 7 \\
\hline & & $\geq 2400$ & 14 & 14 & $\geq 2400$ & $<3$ & NI \\
\hline & & $\geq 2400$ & 4 & NI & 460 & 150 & 28 \\
\hline & & 460 & 43 & NI & 460 & $<3$ & NI \\
\hline & & 460 & 11 & NI & 23 & $<3$ & NI \\
\hline & & 240 & 23 & 23 & 23 & 4 & 4 \\
\hline & & 93 & 43 & 15 & 15 & $<3$ & NI \\
\hline & & 43 & 15 & 4 & 11 & $<3$ & NI \\
\hline & & 21 & $<3$ & NI & $<3$ & $<3$ & NI \\
\hline
\end{tabular}

NI:Notisolated

*The lots were composed of heads of lettuce taken on different days.

It is important to evaluate the results obtained from lots 1 and 2 separately to those obtained from lot 3, because the producer had difficulties maintaining good organic production practices throughout the period of this study. Contamination levels observed in samples taken from lots 1 and 2 were below Brazilian legislation limits, most likely because the practices required by the certification agency were being applied on the farm when those samples were collected.
Rodrigues et al. (2014) observed that unsanitized organic lettuce showed $E$. coli counts above the limit set by Brazilian legislation, but that all sanitized

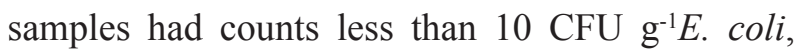
which reinforces the importance of lettuce washing.

Mukherjee et al. (2004) evaluated sanitary condition in 32 organic producers, eight of them certified and 24 uncertified. Lettuce grown by certified producers was not contaminated with $E$. coli; however, $30 \%$ of the samples collected from 
non-certified properties were contaminated with the bacterium. This reinforces the importance of complying with the requirements established by the organic certification.

Gomes Neto et al. (2012) reported that 80\% $(24 / 30)$ of lettuce samples produced by organic system had counts of coliform at $45^{\circ} \mathrm{C}$ above the limit tolerated by Brazilian legislation, and also contained intestinal parasites, both of which indicated very poor sanitary conditions in production. Those results showed a total lack of control, and compliance to, the production steps required by Brazilian agencies of organic production certification.

Salmonella spp. was not isolated in the organic lettuce samples analyzed in this study. Other studies that evaluated the microbiological contamination of lettuce produced by organic, conventional, and hydroponic systems also did not detect Salmonella spp. (Oliveira et al., 2010; GOMES NETO et al., 2012.). Conversely, Arbos et al. (2010) analyzed lettuce and carrots produced in thirteen organic certified farms in the metropolitan region of Curitiba, Parana, Brazil, and found samples with coliform at $45{ }^{\circ} \mathrm{C}$ counts higher than the limit tolerated by the Brazilian legislation, as well as the presence of Salmonella spp. and parasites.

\section{Microbiological evaluation of irrigation water}

The quality and safety of vegetables depend on the proper use of water for irrigation and good practices during harvest, transport, storage, and handling (OLIVEIRA et al., 2011). It is important to mention that the source of water used for irrigation at the farms studied was not the same as that of the water used for washing the lettuce. Resolution $\mathrm{n}^{\circ} 357$ of March 2005 of CONAMA (BRASIL, 2005) establishes that the water used for irrigation of vegetables should not have a count higher than $2.0 \times 10^{2} \mathrm{CFU}$ of coliform at $45^{\circ} \mathrm{C}$ or E. coli per $100 \mathrm{~mL}$ of water. Thus, $50 \%(4 / 8)$ of the irrigation water samples had counts above the limit set by Brazilian legislation. Among the four properties evaluated in this study, only farm A had satisfactory results for the contamination of water used for irrigation $\left(<2 \times 10^{2} \mathrm{MPN}\right.$ in $100 \mathrm{~mL}$ of water. Wachtel et al. (2002) and Barker-Reid et al. (2009) have reported that the use of non-contaminated water for irrigation of fruits and produce may minimize the risk of contamination by pathogenic bacteria; however, the results of this study did not show a relationship between irrigation water contamination and the contamination of lettuce samples.

\section{Conclusion}

The results of this study indicate that most of the lettuce samples produced by conventional cropping systems had good sanitary conditions during production. For organic lettuce, when good manufacturing practices were not applied, contamination remained at high levels even after sanitization. The water used for lettuce irrigation on farms $\mathrm{B}, \mathrm{C}$ and $\mathrm{D}$ had counts of $E$. coli higher than $10^{2} \mathrm{MPN}$ per $100 \mathrm{~mL}$; however, these unsatisfactory results did not adversely affect the level of lettuce contamination with E.coli.

\section{Acknowledgements}

The authors thank the staff of the Coordination of Improvement of Higher Education (CAPES) for granting the Master's scholarship to Natalia H. Niguma, the National Council for Scientific and Technological Development (CNPq) for financial support, Nilson Ladeia Carvalho from the Technical Assistance Institute and Rural Extension of Paraná (EMATER), who organized the visits to the farms, and the farmers who donated the samples of lettuce analyzed in this study. 


\section{References}

ABREU, M. O.; JUNQUEIRA, A. M. R.; PEIXOTO, J. R.; OLIVEIRA, S. A. Qualidade microbiológica e produtividade de alface sob adubação química e orgânica. Ciência e Tecnologia de Alimentos, Campinas, v. 30, p. 108-118, 2010. Suplemento 1.

ALVES, J.; MARQUES, V. V.; PEREIRA, L. F. P.; HIROOKA, E. Y.; OLIVEIRA, T. C. R. M. Multiplex PCR for the detection of Campylobacter spp. and Salmonella spp. in chicken meat. Journal of Food Safety, Malden, v. 32, n. 3, p. 345-350, 2012.

ARBOS, K. A.; FREITAS, R. J. S.; STERTZ, S. C.; CARVALHO, L. A. Segurança alimentar de hortaliças orgânicas: aspectos sanitários e nutricionais. Ciência e Tecnologia de Alimentos, Campinas, v. 30, p. 215-220, 2010. Suplemento 1.

BARKER-REID, F.; HARAPAS, D.; ENGLEITNER, S.; KREIDI, S.; HOLMES, R.; FAGGIAN, R. Persistence of Escherichia coli on injured iceberg lettuce in the field, overhead irrigated with contaminated water. Journal of Food Protection, Des Moines, v. 72, n. 3, p. 458-464, 2009.

BRASIL. Ministério da Saúde. Agência Nacional de Vigilância Sanitária. Resolução n. 12, de 2 janeiro de 2001. Regulamento técnico sobre padrões microbiológicos para alimentos. Diário Oficial [da] União, Brasília, 10 jan. 2001.

Ministério da Saúde. Portaria ${ }^{\circ} 2914$, de 12 de dezembro de 2011. Dispõe sobre os procedimentos de controle e de vigilância da qualidade da água para consumo humano e seu padrão de potabilidade. Diário Oficial [da] União, Brasília, 14 jan. 2012.

Ministério do Meio Ambiente. Conselho Nacional do Meio Ambiente. Resolução n ${ }^{\circ}$ 357, de 17 de Março de 2005. Dispõe sobre a classificação dos corpos de água e diretrizes ambientais para o seu enquadramento, bem como estabelece as condições e padrões de lançamento de efluentes, e dá outras providências. Diário Oficial [da] União, Brasília, 18 mar. 2005.

CENTERS FOR DISEASE CONTROL AND PREVENTION - CDC. Reports of selected E. coli outbreaks investigation. Available at: $<\mathrm{http} / / / \mathrm{www} . c d c$. gov/ecoli/outbreaks.html . Accessed at: 11 mar. 2014a.

CENTERS FOR DISEASE CONTROL AND PREVENTION - CDC. Outbreaks involving Salmonella. Available at: $<$ http://www.cdc.gov/salmonella/outbreaks. html>. Accessed at: 11 mar. 2014b.

CHAO, W. L. Evaluation of Colilert-18 for the detection of coliform and Escherichia coli in tropical fresh water.
Letters in Applied Microbiology, Malden, v. 42, n. 2, p. 115-120, 2006.

DOYLE, M. P.; ERICKSON, M. C. Summer meeting 2007 - the problems with fresh produce: an overview. Journal of Applied Microbiology, Malden, v. 105, n. 2, p. 317-330, 2008.

GOMES NETO, N. J.; PESSOA, R. M. L.; QUEIROGA, I. M. B. N.; MAGNANI, M.; FREITAS, F. I. S.; SOUZA, E. L.; MACIEL, J. R. Bacterial counts and occurrence of parasites in lettuce (Lactuca sativa) from different cropping systems in Brazil. Food Control, Amsterdam, v. 28, n. 1, p. 47-51, 2012.

GUAN, T. T. Y.; BLANK, G.; HOLLEY, R. A. Survival of pathogenic bacteria in pesticide solutions and on treated tomato plants.Journal of Food Protection, Des Moines, v. 68, n. 2, p. 296-304, 2005.

JOHANNESSEN, G. S.; LONCAREVIC, S.; KRUSE, H. Bacteriological analysis of fresh produce in Norway. International Journal of Food Microbiology, Torino, v. 77, n. 3, p. 199-204, 2002.

MUKHERJEE, A.; SPEH, D.; DYCK, E.; DIEZGONZALEZ, F. Preharvest evaluation of coliforms, Escherichia coli, Salmonella and Escherichia coli O157:H7 in organic and conventional produce grown by Minnesota farmers. Journal of Food Protection, Des Moines, v. 67, n. 5, p. 894-900, 2004.

OLIVEIRA, M.; USALL, J.; VIÑAS, I.; ANGUERA, M.; GATIUS, F.; ABADIAS, M. Microbiological quality of fresh lettuce from organic and conventional production. Food Microbiology, London, v.27, n. 5, p. 679-684, 2010.

OLIVEIRA, M. A.; SOUZA, V. M.; BERGAMINI, A. M. M.; MARTINIS, E. C. P. Microbiological quality of ready-to-eat minimally processed vegetables consumed in Brazil. Food Control, Amsterdam, v. 22, n. 8, p. 14001403, 2011.

RODRIGUES, R. Q.; LOIKOA, M. R.; PAULA, C. M. D.; HESSEL, C. T.; JACXSENS, L.; UYTTENDAELE, M.; BENDER, R. J.; TONDO, E. C. Microbiological contamination linked to implementation of good agricultural practices in the production of organic lettuce in Southern Brazil. Food Control, Amsterdam, v. 42, p. 152-164, 2014.

SILVA, M. P.; CAVALLI, D. R.; OLIVEIRA, T. C. R. M. Avaliação do padrão coliformes a $45^{\circ} \mathrm{C}$ e comparação da eficiência das técnicas dos tubos múltiplos e Petrifilm EC na detecção de coliformes totais e Escherichia coli em alimentos. Ciência e Tecnologia de Alimentos, Campinas, v. 26, n. 2, p. 352-359, 2006. 
SILVA, N.; JUNQUEIRA, V. C. A.; SILVEIRA, N. F. A.; TANIWAKI, M. H.; SANTOS, R. F. S.; GOMES, R. A. R.; OKAZAKI, M. M. Manual de métodos de análise microbiológica de alimentos. 3. ed. São Paulo: Varela, 2007a. 536 p.

. Manual de métodos de análise microbiológica de alimentos. 3. ed. São Paulo: Varela, 2007b. 536 p.

SECRETARIA DE VIGILÂNCIA EM SAÚDE - SVS. Dados Epidemiológicos - DTA período de 2000 a 2014.2016. Disponível em: <http://www.anrbrasil.org. br/new/pdfs/2014/3_PAINEL_1_Apresentacao RejaneA lvesVigilanciaEpidemiologica-VE-DTA-Agosto_2014 PDF.pdf $>$. Acesso em: 10 jul. 2016.
TAKAYANAGUI, O. M.; OLIVEIRA, C. D.; BERGAMINI, A. M. M.; CAPUANO, D. M.; OKINO; M. H. T.; FEBRÔNIO, L. H. P.; CASTRO E SILVA, A. A. M. C.; OLIVEIRA, M. A.; RIBEIRO, E. G. A.; TAKAYANAGUI, A. M. M. Fiscalização de verduras comercializadas no município de Ribeirão Preto, São Paulo. Revista Sociedade Brasileira de Medicina Tropical, Uberaba, v. 34, n. 1, p. 37-41, 2001.

WACHTEL, M. R.; WHITEHAND, L. C.; MANDRELL, R. E. Association of Escherichia coli O157:H7 with preharvest leaf lettuce upon exposure to contaminated irrigation water. Journal of Food Protection, Des Moines, v. 65 , n. 1 , p. $18-25,2002$. 
